\title{
Implications for the Predictivity of Cell-Based Developmental Toxicity Assays Developed Two Decades Apart
}

\author{
Satoshi Kawamura, Nobuyuki Horie, Noriko Okahashi ${ }^{\Psi}$ and Hashihiro Higuchi \\ Environmental Health Science Laboratory, Sumitomo Chemical Co., Ltd., Osaka, Japan
}

\begin{abstract}
Many in vitro developmental toxicity assays have been proposed over several decades. Since the late 1980s, we have made intermittent attempts to introduce in vitro assays as screening tests for developmental toxicity of inhouse candidate products. Two cell-based assays which were developed two decades apart were intensively studied. One was an assay of inhibitory effects on mouse ascites tumor cell attachment to a concanavalin A-coated plastic sheet surface (MOT assay), which we studied in the early days of assay development. The other was an assay of inhibitory effects on the differentiation of mouse embryonic stem cell to beating heart cells (EST assay), which we assessed more recently. We evaluated the suitability of the assays for screening in-house candidates. The concordance rates with in vivo developmental toxicity were at the $60 \%$ level. The EST assay classified chemicals that inhibited cell proliferation as embryo-toxic. Both assays had a significant false positive rate. The assays were generally considered unsuitable for screening the developmental toxicity of our candidate compounds. Recent test systems adopt advanced technologies. Despite such evolution of materials and methods, the concordance rates of the EST and MOT systems were similar. This may suggest that the fundamental predictivity of in vitro developmental toxicity assays has remained basically unchanged for decades. To improve their predictivity, in vitro developmental toxicity assays should be strictly based on elucidated pathogenetic mechanisms of developmental toxicity.
\end{abstract}

Key words: Ascites tumor cells, Developmental toxicity, Embryonic stem cells, In vitro assays, Predictivity

\section{INTRODUCTION}

In vitro developmental toxicity assays have been proposed and used for decades. Many of them were expected to have potential value as developmental toxicity risk assessors. In the summer of 1981, the leading teratologists of the time gathered at DeGray Lake State Park, Arkansas, to participate in a workshop on in vitro teratogenesis testing (1). At the workshop, a representative range of testing systems was presented. They involved the use of rodent whole embryos (2), chick embryos (3), hydras (4), planarians (5), drosophilas (6), poxviruses (7), embryonic limb buds (8), mesenchymal cells from embryonic palate (9), neural crest cells (10), and tumor cells attachment to concanavalin A-coated surfaces (11). Fishes (the sea minnow, the platy fish, the medaka fish, the zebra fish, and the trout) and amphibians such as frogs (12) were the other lower vertebrate embryos that were used or recommended for use in teratological studies. Some of them are still used in in vitro developmental toxicity testing systems. Remarkable progress in technology has been made following the workshop. The technological advancement of materials and methods has been adopted in recent in vitro screening assays.
Correspondence to: Satoshi Kawamura, Environmental Health Science Laboratory, Sumitomo Chemical Co., Ltd., 1-98, Kasugade naka 3-chome, Konohana-ku, Osaka 554-8558, Japan

E-mail: kawamuras2@sc.sumitomo-chem.co.jp

"Present Address: Medical Information, Sumitomo Dainippon Pharma Co., Ltd., 6-8, Doshomachi 2-chome, Chuo-ku, Osaka 541-0045, Japan
This is an Open-Access article distributed under the terms of the Creative Commons Attribution Non-Commercial License (http:// creativecommons.org/licenses/by-nc/3.0) which permits unrestricted non-commercial use, distribution, and reproduction in any medium, provided the original work is properly cited. 
We have been making attempts to introduce in vitro developmental toxicity assays including cell-based assays, organ culture systems, and whole embryo culture for the screening of developmental toxicity of in-house candidate chemicals under development since the late 1980s. The two in vitro cell-based assays were intensively studied using existing chemicals and in-house candidates under development to determine their suitability as tests for developmental toxicity. One was an assay to test the ability of chemicals to inhibit mouse ascites tumor cell attachment to concanavalin A-coated plastic sheet surfaces (MOT assay). The encouraging results presented at the 1981 workshop (11) were published $(13,14)$. Our assessment of the MOT assay began at the end of the 1980s. The other was the embryonic stem cell test (EST assay) and was vigorously evaluated and discussed as a promising alternative to animal test (15-17). The EST assay tests for chemical inhibition of mouse embryonic stem cell differentiation into contracting cardiomyocytes. We expected that the accuracy of prediction would be increased by technological improvements in materials and methods such as the usage of embryonic stem cells. Evaluation of EST assay began relatively recently.

The rate of concordance between the MOT assay results and the in vivo test results was about $60 \%$. In spite of the technological evolution represented by the EST assay, the concordance remained at a similar level. In the EST assay, cell proliferation inhibitors tended to be classified as embryo-toxic. Both assays showed a significant false positive rate. We concluded that both assays were generally unsuitable to screen our candidate compounds for developmental toxicity. The predictivity of in vitro developmental toxicity assays still needs to be improved.

\section{MATERIAL AND METHODS}

Chemicals. Chemicals other than in-house candidates were of reagent grade.

- Assessment of the MOT assay with existing chemicals: Ethanol, dimethyl sulfoxide, chlorpromazine, aspirin, cyclophosphamide, 6-amino nicotinamide, diethyl stilbestrol, phenytoin, cortisone, aminopterin, all-trans retinoic acid, and 5-fluorouracil were used as developmentally toxic compounds. Saccharin, amaranth, L-ascorbic acid, L-glutamic acid, diphenhydramine, histamine, isoniazid, and pyridoxine were used as non-developmentally toxic compounds.

- Assessment of the EST assay with existing chemicals, used previously in European Centre for the Validation of Alternative Methods (ECVAM) validation studies: Strong embryotoxic compounds included methotrexate, all-trans retinoic acid, 6 aminonicotinic acid, bromodeoxyuracil, and hydroxyurea. Weak embryotoxic compounds included lithium, boric acid, valproic acid, dimethadi- one, salicylic acid, and methoxyacetic acid. Non-embryotoxic compounds included penicillin G, saccharin, acrylamide, camphor, diphenhydramine, and dimethylphthalate.

- Assessment with in-house chemicals: Test chemicals were supplied by Sumitomo Chemical Co., Ltd. In vivo teratogenic potential was determined in-house. Fortytwo in-house chemicals were used for the assessment of the MOT assay and 32 for EST. The two sets of in-house chemicals partially overlapped. The chemicals were dissolved in the appropriate solvent (phosphate-buffered saline [PBS], dimethyl sulfoxide, or ethanol) to an appropriate concentration. The tested concentrations for some chemicals were limited by solubility.

MOT assay. MOT assay was conducted using a previously described method (11). Procedures involving animals and their care were in compliance with Japanese law and were approved by our company's IACUC.

- Concanavalin A-coated disks: Disks $(1.25 \mathrm{~cm}$ diameter) were cut from polyethylene sheets. The disks were floated overnight at room temperature on a solution of PBS containing $2.5 \%$ glutaraldehyde and $50 \mu \mathrm{g} / \mathrm{mL}$ concanavalin A, washed in PBS, and stored in $10 \mathrm{mM}$ Tris- $\mathrm{HCl}$ (pH 7.4) containing $0.3 \mathrm{M}$ glycine, $1 \mathrm{mM}$ manganese chloride, and $1 \mathrm{mM}$ sodium azide. Bovine serum albumin coated disks served as non-attachment controls.

- Tumor cells and chemical exposure: Female ICR mice purchased from Japan SLC, Inc. (Shizuoka, Japan) were inoculated with $5 \times 10^{5}$ ascitic mouse tumor cells (Ehrlich ascites cells from Sumitomo Pharmaceuticals Co., Ltd., Osaka, Japan) about 2 weeks before use. The cells were harvested, washed in PBS, and re-suspended in Eagle's minimal essential medium with 5\% fetal bovine serum. For radioactive labeling, the cells were incubated with $12.5 \mu \mathrm{Ci}^{3} \mathrm{H}$ thymidine per $10^{8}$ cells at $37^{\circ} \mathrm{C}$ for $1 \mathrm{hr}$ with gentle agitation. After washing three times in PBS, aliquots $(1 \mathrm{~mL})$ of labeled cells at $10^{7}$ cells $/ \mathrm{mL}$ were incubated with various concentrations of the test agent for $30 \mathrm{~min}$ at $37^{\circ} \mathrm{C}$. Test solutions were prepared by serial dilution. The maximum concentration was set at a concentration that is lethal to a majority of the cells or the maximum water soluble concentration.

- Assay for inhibitory activity against attachment: Three or four disks were placed in a plastic Petri dish (35 $\mathrm{mm}$ diameter) with lectin-coated side up, permitting adhesion of the disks to the bottom surface of the dish. The cells were poured into the dish and allowed to sediment onto the disks for $20 \mathrm{~min}$. The disks were then removed with fine forceps, washed in PBS, and radioassayed. The radioactivity of the disks was quantified by conventional liquid scintillation counting with a Packard Tri-Carb 460 CD. The cell suspensions were incubated with $0.1 \%$ trypan blue and examined for the presence of dead cells. Dead cells do not attach to lectin-coated surfaces, hence, 
detached trypan-blue positive cells were not considered to be the product of "true" inhibition.

- Analysis of data: The adherent cell count on the bovine serum albumin-coated disks (non-attachment control) was subtracted from the average adherent cell count on concanavalin A-coated disks. The results were plotted as a percentage of attachment of vehicle-treated cells to concanavalin A-coated disks. More than two experimental runs were conducted for each chemical. When the percentages of the attached cells exposed to a chemical were lower than those of cell viability, the chemical was judged to inhibit the attachment of viable cells and classified as positive.

EST assay. EST assay was conducted as previously described (18) with modification. Each test chemical was classified into three categories based on published criteria (18).

- Cell culture: BALB/c 3 T3 (American Type Culture Collection, VA, USA) cells were maintained in Dulbecco's modified Eagle's medium (DMEM) supplemented with $10 \%$ fetal bovine serum, $4 \mathrm{mM}$ glutamine, $100 \mathrm{U}$ penicillin $/ \mathrm{mL}$, and $0.1 \mathrm{mg}$ streptomycin $/ \mathrm{mL}$. Embryonic stem (ES) cells (American Type Culture Collection) were maintained in serum-free media for mouse ES cells with $0.1 \%$ mercaptoethanol, and 1,000 U leukemia inhibitory factor (LIF)/mL. As differentiation medium, DMEM containing $1 \%$ non-essential amino acids, $0.1 \%$ mercaptoethanol, $100 \mathrm{U}$ penicillin $/ \mathrm{mL}, 0.1 \mathrm{mg}$ streptomycin $/ \mathrm{mL}$, and $15 \%$ fetal bovine serum was used.

- Cytotoxicity assay using ES cells and 3T3 cells: A thousand cells were seeded into each well of a 96-well plate and grown in the presence of a concentration range of a test chemical diluted in culture medium in the absence of LIF. After 4 days of culture, the viability of the cells was determined using Cell Counting Kit-8 (Dojindo Laboratories, Kumamoto, Japan). The cells were treated with different concentrations of the test chemicals and the cytotoxicity for each cell line was expressed as the concentration inhibiting growth by $50 \%$ of the control level $\left(\mathrm{IC}_{50} 3 \mathrm{~T} 3\right.$ and $\left.\mathrm{IC}_{50} \mathrm{ES}\right)$.

- Differentiation assay using ES cells: Four hundred undifferentiated ES cells in droplets of $20 \mu \mathrm{L}$ were seeded onto the bottom of the lid of a culture dish and grown for 3 days in hanging drop culture in the presence of a concentration range of test chemical diluted in differentiation medium to allow differentiation into embryoid bodies (EBs). After 3 days in hanging drop culture, the EBs were transferred to Petri dishes containing differentiation medium with the test chemical for another 2 days. On day 5, the EBs were seeded singly into one well of a 24-well tissue culture plate (containing the test chemical) to allow adherence and outgrowth of the EBs, and the development of contracting cardiomyocytes. Differentiation was assessed by microscopic inspection of the EBs on day 10. The percentage of EBs developing contracting cardiomyocytes was determined and compared to that in the control. The EBs were treated with different concentrations of the test chemicals and the inhibition of differentiation is expressed as the concentration of test chemical that inhibited the development of contracting cardiomyocytes by $50 \%$ of the control $\left(\mathrm{ID}_{50}\right)$.

- Biostatistics: Previously described prediction model consisting of linear discriminant functions and classification criteria (18) was used. Endpoints $\left(\mathrm{ID}_{50}, \mathrm{IC}_{50} \mathrm{ES}\right.$, and $\mathrm{IC}_{50} 3 \mathrm{~T} 3$ ) of test chemicals were applied as variables in the linear discriminant functions and, then, embryotoxicity of each test chemical was classified as non, weak or strong according to the classification criteria. Linear discriminant functions are expressed in the following equations:

$$
\begin{gathered}
\text { Function I: } 5.9157 \log \left(\mathrm{IC}_{50} 3 \mathrm{~T} 3\right)+3.500 \log \left(\mathrm{IC}_{50} \mathrm{ES}\right) \\
-5.307\left(\mathrm{IC}_{50} 3 \mathrm{~T} 3-\mathrm{ID}_{50}\right) / \mathrm{IC}_{50} 3 \mathrm{~T} 3-15.72 \\
\begin{aligned}
\text { Function II: } & 3.651 \log \left(\mathrm{IC}_{50} 3 \mathrm{~T} 3\right)+2.394 \log \left(\mathrm{IC} \mathrm{I}_{50} \mathrm{ES}\right) \\
- & 2.033\left(\mathrm{IC}_{50} 3 \mathrm{~T} 3-\mathrm{ID}_{50}\right) / \mathrm{IC}_{50} 3 \mathrm{~T} 3-6.85 \\
\text { Function III: } & -0.125 \log \left(\mathrm{IC}_{50} 3 \mathrm{~T} 3\right)-1.917 \log \left(\mathrm{IC}_{50} \mathrm{ES}\right) \\
+ & 1.500\left(\mathrm{IC}_{50} 3 \mathrm{~T} 3-\mathrm{ID}_{50}\right) / \mathrm{IC}_{50} 3 \mathrm{~T} 3-2.67
\end{aligned}
\end{gathered}
$$

When the result of function I exceeds those of functions II and III, the chemical is classified as non-embryotoxic. When the function II result is larger than those of functions I and III, the chemicals is weakly embryotoxic. When the function III result is the largest, the chemical is strongly embryotoxic.

\section{RESULTS}

MOT assay. The principle of the MOT assay is to identify chemicals that interfere with energy-dependent attachment of tumor cells to the concanavalin A-coated surfaces of plastic disks. Cell-to-cell or cell-to-extracellular matrix interaction plays a key role in development. Cell-cell interaction during embryogenesis requires metabolic energy. Tumor cell attachment to concanavalin A may mimic cell-cell interactions in embryos. This possible model of cell-cell interactions in embryos was used in the in vitro MOT assay $(11,13,19)$. Treatment of tumor cells with dinitrophenol, an inhibitor of ATP production, inhibited cell attachment without affecting cell viability. Fig. 1 shows a typical curve of cell attachment inhibition by dinitrophenol. Viability of cells was similar to that of the control even at the highest dose tested. The percentage of attachment was reduced in a dose-dependent manner. Few cells attached to the concanavalin A-coated surfaces of plastic disks at $\geq 12.5 \mu \mathrm{g} / \mathrm{mL}$ of dinitrophenol. This supports the energy dependence of cell attachment to concanavalin A in the MOT assay.

As the first step towards introducing the assay into our facility, we studied the MOT assay using existing chemi- 


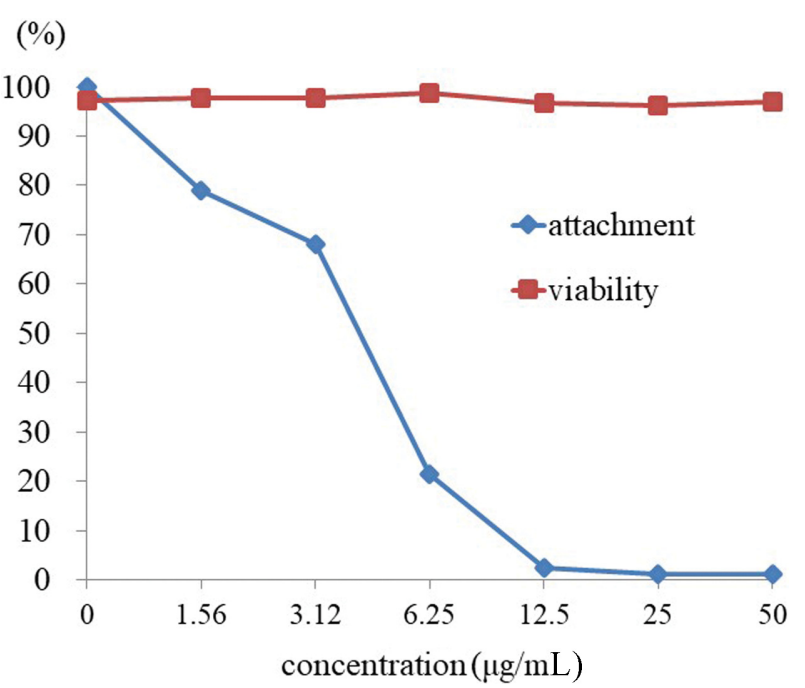

Fig. 1. Typical curves showing the relationship of cell attachment inhibition and cell viability with dinitrophnol concentration in the MOT assay. Percentage of cell attachment to concanavalin A was reduced in a dose-dependent manner. Few cells attached to concanavalin A-coated surface of plastic disks at $\geq 12.5 \mu \mathrm{g} / \mathrm{mL}$. Cell viability was not affected at the highest concentration $(50 \mu \mathrm{g} / \mathrm{mL})$.

cals to determine its suitability as a screen for developmental toxicity. Data regarding the in vivo developmental toxicity of the chemicals are publicly available. The concordance of the MOT assay results with the in vivo data of existing chemicals was $65 \%$ (Table 1). Fifteen out of 20 chemicals inhibited cell attachment. A majority of the developmentally toxic chemicals, 10 out of 12 , were correctly classified as positive. However, 5 out of 8 nondevelopmentally toxic chemicals also inhibited cell attachment, and were falsely judged as positive. Next, we evaluated in-house chemicals that had been tested for develop- mental toxicity in rats and, in some cases, also rabbits. The results of the MOT assay with the in-house chemicals were comparable to those with the existing chemicals. The concordance rate was $64 \%$ (Table 1). Fifteen out of 19 developmentally toxic chemicals inhibited cell attachment, and so did half of the non-developmental toxicants. At the time we conducted the MOT assay, we had promising candidate chemicals for a certain application, some of which caused developmental toxicity in rats. Subsequent structurally and bioactively similar candidates were examined for developmental toxicity concurrently in a smallscale study in rats and using the MOT assay. The concordance between in vitro and in vivo study results was $51 \%$ (Table 1). Half of the developmentally toxic and non-toxic candidates were falsely classified.

With 99 chemicals including existing chemicals, inhouse chemicals, and a group of structurally, bioactively similar candidate chemicals, the overall concordance rate between the MOT assay in our facility and in vivo data was $60 \%$ (Table 1). The results show that half of developmentally non-toxic chemicals in each of the three different chemical groups inhibited cell attachment in the MOT assay (Table 1). Taken together, 24 out of 45 developmentally non-toxic chemicals inhibited cell attachment. Accordingly, it may be concluded that the MOT assay exhibits a significant false positive rate.

EST assay. The EST assay was initially conducted with 17 chemicals that were used in the ECVAM validation study (20). The concordance rate was $65 \%$ (Table 2). The strong embryotoxic chemicals were well detected. However, half of the weak embryotoxic chemicals in vivo were classified as non-toxic in vitro, and the other half as weakly toxic. The classification of non-embryotoxic chemicals in vivo was also evenly divided between non- and weakly toxic in vitro. The concordance rate $(65 \%)$ was

Table 1. Comparison of in vitro toxicity assay by attachment inhibition with in vivo developmental assay

\begin{tabular}{|c|c|c|c|c|c|}
\hline \multirow{2}{*}{ Test chemicals } & \multirow{2}{*}{ In vivo } & \multicolumn{3}{|c|}{ In vitro } & \multirow{2}{*}{ Concordance } \\
\hline & & Inhibitory & Noninhibitory & Total & \\
\hline \multirow[t]{3}{*}{ Existing chemicals } & Developmentally toxic & 10 & 2 & 12 & $65 \%$ \\
\hline & Developmentally nontoxic & 5 & 3 & 8 & \\
\hline & Total & 15 & 5 & 20 & \\
\hline \multirow[t]{3}{*}{ In-house chemicals } & Developmentally toxic & 15 & 4 & 19 & $64 \%$ \\
\hline & Developmentally nontoxic & 11 & 12 & 23 & \\
\hline & Total & 26 & 16 & 42 & \\
\hline \multirow{3}{*}{$\begin{array}{l}\text { A group of structurally, bioactively } \\
\text { similar chemicals }\end{array}$} & Developmentally toxic & 13 & 10 & 23 & $51 \%$ \\
\hline & Developmentally nontoxic & 8 & 6 & 14 & \\
\hline & Total & 21 & 16 & 37 & \\
\hline \multirow[t]{3}{*}{ All chemicals tested } & Developmentally toxic & 38 & 16 & 54 & $60 \%$ \\
\hline & Developmentally nontoxic & 24 & 21 & 45 & \\
\hline & Total & 62 & 37 & 99 & \\
\hline
\end{tabular}


Table 2. Comparison of in vitro toxicity classification assay by EST with in vivo developmental assay

\begin{tabular}{|c|c|c|c|c|c|}
\hline \multirow{2}{*}{ Test chemicals } & \multirow{2}{*}{$\begin{array}{c}\text { In vivo } \\
\text { developmental toxicity }\end{array}$} & \multicolumn{3}{|c|}{ In vitro classification } & \multirow{2}{*}{ Concordance } \\
\hline & & Strong & Weak & Non & \\
\hline \multirow[t]{3}{*}{ ECVAM validation chemicals } & Strong & 5 & 0 & 0 & \\
\hline & Weak & 0 & 3 & 3 & $65 \%$ \\
\hline & Non & 0 & 3 & 3 & \\
\hline \multirow{2}{*}{ In-house chemicals ${ }^{\mathrm{a}}$} & Developmentally toxic & 0 & 11 & 0 & \\
\hline & Developmentally nontoxic & 2 & 19 & 0 & \\
\hline
\end{tabular}

${ }^{a}$ Many of in-house chemicals were investigated for developmental toxicity in one species (rats), and could not be classified according to Genshow et al (20).

In vivo developmental toxicity of in-house chemicals was classified as either developmentally toxic or non-toxic.

Table 3. Distribution of in vitro classification and in vivo developmental toxicity classification of chemicals by ECVAM validation according to $\mathrm{IC}_{50} \mathrm{ES}$ range

\begin{tabular}{|c|c|c|c|c|c|c|c|}
\hline \multirow{2}{*}{$\begin{array}{c}\mathrm{IC}_{50} \mathrm{ES} \\
(\mu \mathrm{g} / \mathrm{mL})\end{array}$} & \multirow{2}{*}{$\begin{array}{c}\text { Number of } \\
\text { test chemicals }\end{array}$} & \multicolumn{3}{|c|}{ In vitro classification } & \multicolumn{3}{|c|}{ In vivo developmental toxicity } \\
\hline & & Strong & Weak & Non & Strong & Weak & Non \\
\hline$<0.1$ & 3 & 2 & 0 & 1 & 3 & 0 & 0 \\
\hline $0.1-1$ & 1 & 1 & 0 & 0 & 1 & 0 & 0 \\
\hline $1-10$ & 2 & 2 & 0 & 0 & 2 & 0 & 0 \\
\hline $10-100$ & 3 & 0 & 3 & 0 & 0 & 1 & 2 \\
\hline $100-1000$ & 9 & 0 & 6 & 3 & 0 & 6 & 3 \\
\hline$>1000$ & 2 & 0 & 0 & 2 & 0 & 0 & 2 \\
\hline
\end{tabular}

Data were retrieved from Appendix 2 (laboratory code I) of the publication by Genschow et al (20).

lower than that in the ECVAM validation study (78\%) (20). Then, we evaluated 32 in-house chemicals and because many of them were investigated for developmental toxicity in one species (rats), they could not be separated into strong, weak, and non-embryotoxic groups according to Genschow et al (20). In this study, the in vivo embryotoxicity of the in-house chemicals was classified as either developmentally toxic or non-toxic based on the results of the in-house animal studies. Based on the results of the EST assay, almost all the in-house chemicals were weakly toxic regardless of their in vivo embryotoxicity (Table 2). Similarly, in a pharmaceutical industry assessment, a majority of in-house chemicals were classified as weakly toxic in the EST assay (21).

We analyzed the results of the EST assay to determine why the EST assay tends to over-classify chemicals as weakly toxic. We noticed that EST classification might be, in part, explained by cell growth inhibition. The results of sorting ECVAM validation of the test chemicals by $\mathrm{IC}_{50} \mathrm{ES}$ revealed that classification by the prediction model (18) might be consistent with the degree of cell growth inhibition (Table 3). This may reflect the relationship between the in vivo embryotoxicity of chemicals selected for prediction model setting and cell growth inhibition, suggesting the basis for prediction may primarily be cell growth inhibition. The results with the in-house chemicals were sorted by $\mathrm{IC}_{50} \mathrm{ES}$ (Table 4). $\mathrm{IC}_{50} \mathrm{ES}$ for the in-house chemicals mainly ranged from 1 to $100 \mu \mathrm{g} / \mathrm{mL}$ regardless of the in vivo developmental toxicity. All the chemicals within this concentration range were classified as weak in vitro. Two chemicals within $\mathrm{IC}_{50} \mathrm{ES}$ range of 0.1 to $1 \mu \mathrm{g} / \mathrm{mL}$ were classified as strong in vitro although they produced

Table 4. Distribution of in vitro classification and in vivo developmental toxicity of in-house chemicals at Sumitomo Chemical Co. Ltd according to $\mathrm{IC}_{50} \mathrm{ES}$ range

\begin{tabular}{|c|c|c|c|c|c|c|}
\hline \multirow{2}{*}{$\begin{array}{l}\mathrm{IC}_{50} \mathrm{ES} \\
(\mu \mathrm{g} / \mathrm{mL})\end{array}$} & \multirow{2}{*}{$\begin{array}{l}\text { Number of } \\
\text { test chemicals }\end{array}$} & \multicolumn{3}{|c|}{ In vitro classification } & \multicolumn{2}{|c|}{ In vivo developmental toxicity } \\
\hline & & Strong & Weak & Non & Developmentally toxic & Developmentally nontoxic \\
\hline$<0.1$ & 0 & 0 & 0 & 0 & 0 & 0 \\
\hline $0.1-1$ & 2 & 2 & 0 & 0 & 0 & 2 \\
\hline $1-10$ & 6 & 0 & 6 & 0 & 1 & 5 \\
\hline $10-100$ & 22 & 0 & 22 & 0 & 9 & 13 \\
\hline $100-1000$ & 2 & 0 & 2 & 0 & 1 & 1 \\
\hline$>1000$ & 0 & 0 & 0 & 0 & 0 & 0 \\
\hline
\end{tabular}


Table 5. Analysis of the characteristics of the prediction model of EST assay with fictitious values of $\mathrm{IC}_{50} \mathrm{~S}$

\begin{tabular}{|c|c|c|c|c|c|c|c|c|c|c|}
\hline \multirow{2}{*}{$\begin{array}{l}\mathrm{IC}_{50} \mathrm{ES} \\
(\mu \mathrm{g} / \mathrm{mL})\end{array}$} & \multicolumn{3}{|c|}{ Fictitious $\mathrm{IC}_{50} \mathrm{~s}$} & \multirow[b]{2}{*}{$\mathrm{ID}_{50} / \mathrm{IC}_{50} \mathrm{ES}$} & \multirow{2}{*}{$\begin{array}{c}\text { In vitro } \\
\text { classification }\end{array}$} & \multicolumn{3}{|c|}{ Fictitious $\mathrm{IC}_{50} \mathrm{~s}$} & \multirow[b]{2}{*}{$\mathrm{IC}_{50} 3 \mathrm{~T} 3 / \mathrm{IC}_{50} \mathrm{ES}$} & \multirow{2}{*}{$\begin{array}{l}\text { In vitro } \\
\text { classification }\end{array}$} \\
\hline & $\begin{array}{c}\mathrm{IC}_{50} 3 \mathrm{~T} 3 \\
\text { fixed }\end{array}$ & $\begin{array}{l}\mathrm{IC}_{50} \mathrm{ES} \\
\text { fixed }\end{array}$ & $\begin{array}{c}\mathrm{ID}_{50} \\
\text { varied }\end{array}$ & & & $\begin{array}{c}\mathrm{IC}_{50} 3 \mathrm{~T} 3 \\
\text { varied }\end{array}$ & $\begin{array}{l}\mathrm{IC}_{50} \mathrm{ES} \\
\text { fixed }\end{array}$ & $\begin{array}{l}\mathrm{ID}_{50} \\
\text { fixed }\end{array}$ & & \\
\hline \multirow[t]{4}{*}{$0.1-1$} & 0.5 & 0.5 & 0.5 & 1 & Strong & 0.1 & 0.5 & 0.5 & 0.2 & Non \\
\hline & 0.5 & 0.5 & 1 & 2 & Strong & 0.125 & 0.5 & 0.5 & 0.25 & Weak \\
\hline & 0.5 & 0.5 & 2 & 4 & Weak & 0.25 & 0.5 & 0.5 & 0.5 & Strong \\
\hline & 0.5 & 0.5 & 2.5 & 5 & Non & 0.5 & 0.5 & 0.5 & 1 & Strong \\
\hline \multirow[t]{3}{*}{$1-10$} & 5 & 5 & 5 & 1 & Weak & 1.25 & 5 & 5 & 0.25 & Non \\
\hline & 5 & 5 & 10 & 2 & Weak & 2.5 & 5 & 5 & 0.5 & Weak \\
\hline & 5 & 5 & 15 & 3 & Non & 5 & 5 & 5 & 1 & Weak \\
\hline \multirow[t]{3}{*}{$10-100$} & 50 & 50 & 50 & 1 & Weak & 12.5 & 50 & 50 & 0.25 & Non \\
\hline & 50 & 50 & 100 & 2 & Non & 25 & 50 & 50 & 0.5 & Weak \\
\hline & & & & & & 50 & 50 & 50 & 1 & Weak \\
\hline \multirow[t]{2}{*}{$100-1000$} & 500 & 500 & 450 & 0.9 & Weak & 500 & 500 & 500 & 1 & Non \\
\hline & 500 & 500 & 500 & 1 & Non & 560 & 500 & 500 & 1.1 & Weak \\
\hline
\end{tabular}

Table 6. Comparison of the $\mathrm{ID}_{50}$ and $\mathrm{IC}_{50} 3 \mathrm{~T} 3$ with the $\mathrm{IC}_{50} \mathrm{ES}$ of in-house chemicals at Sumitomo Chemical Co. LTD by IC ${ }_{50} \mathrm{ES}$ concentration range

\begin{tabular}{|c|c|c|c|c|c|c|c|c|c|}
\hline \multirow{3}{*}{$\begin{array}{l}\mathrm{IC}_{50} \mathrm{ES} \\
(\mu \mathrm{g} / \mathrm{mL})\end{array}$} & \multirow{3}{*}{$\begin{array}{l}\text { Number of } \\
\text { test chemicals }\end{array}$} & \multicolumn{8}{|c|}{ Distribution of ratios of in-house chemicals tested at Sumitomo Chemical } \\
\hline & & \multicolumn{4}{|c|}{$\mathrm{ID}_{50} / \mathrm{IC}_{50} \mathrm{ES}$ ratio } & \multicolumn{4}{|c|}{$\mathrm{IC}_{50} 3 \mathrm{~T} 3 / \mathrm{IC}_{50} \mathrm{ES}$ ratio } \\
\hline & & $0.1-0.5$ & $0.5-1$ & $1-2$ & $2-4$ & $0.1-0.5$ & $0.5-1$ & $1-2$ & $2-4$ \\
\hline$<0.1$ & 0 & 0 & 0 & 0 & 0 & 0 & 0 & 0 & 0 \\
\hline $0.1-1$ & 2 & 0 & 0 & 2 & 0 & 0 & 1 & 0 & 1 \\
\hline $1-10$ & 6 & 1 & 1 & 3 & 1 & 0 & 0 & 5 & 1 \\
\hline $10-100$ & 22 & 5 & 13 & 4 & 0 & 1 & 9 & 12 & 0 \\
\hline $100-1000$ & 2 & 0 & 1 & 1 & 0 & 0 & 0 & 2 & 0 \\
\hline$>1000$ & 0 & 0 & 0 & 0 & 0 & 0 & 0 & 0 & 0 \\
\hline
\end{tabular}

no abnormalities in fetuses.

We examined the characteristics of the prediction model by using simple fictitious $\mathrm{IC}_{50}$ and $\mathrm{ID}_{50}$ values for classification purpose (Table 5). To investigate a possible relationship between $\mathrm{IC}_{50} \mathrm{ES}$ (cell growth) and $\mathrm{ID}_{50}$ (cell differentiation), we classified chemicals according to the prediction model and used various $\mathrm{ID}_{50}$ values with $\mathrm{IC}_{50} \mathrm{ES}$ and $\mathrm{IC}_{50} 3 \mathrm{~T} 3$ values fixed at the median of each concentration range for sorting (left column of Table 5). Chemicals with $\mathrm{IC}_{50} \mathrm{ES}$ in the range of 0.1 to 1,1 to 10 , and 10 to 100 $\mu \mathrm{g} / \mathrm{mL}$ were classified as non-toxic by the prediction model when the $\mathrm{ID}_{50} / \mathrm{IC}_{50} \mathrm{ES}$ ratio was higher than 5,3 , and 2 , respectively. Thus, it was inferred that chemicals with $\mathrm{IC}_{50} \mathrm{ES}$ in the range of 0.1 to $100 \mu \mathrm{g} / \mathrm{mL}$ should have an $\mathrm{ID}_{50} / \mathrm{IC}_{50} \mathrm{ES}$ ratio of 2 or more in order not to be classified as weak or strong by the prediction model. Similarly, a possible relationship between mature $3 \mathrm{~T} 3$ and immature ES cells was investigated with fixed $\mathrm{IC}_{50} \mathrm{ES}$ and $\mathrm{ID}_{50}$ values, and various $\mathrm{IC}_{50} 3 \mathrm{~T} 3$ values (right column of Table 5). It was also suggested that chemicals with $\mathrm{IC}_{50} \mathrm{ES}$ in the range of 0.1 to $100 \mu \mathrm{g} / \mathrm{mL}$ might be classified as non-toxic when the $\mathrm{IC}_{50} 3 \mathrm{~T} 3 / \mathrm{IC}_{50} \mathrm{ES}$ ratio was lower than 0.5. Accord- ingly, it is likely that the prediction model classifies a chemical as weak or strong when the $\mathrm{ID}_{50} / \mathrm{IC}_{50} \mathrm{ES}$ ratio is lower than 2 and the $\mathrm{IC}_{50} 3 \mathrm{~T} 3 / \mathrm{IC}_{50} \mathrm{ES}$ ratio is higher than 0.5. The $\mathrm{IC}_{50}$ and $\mathrm{ID}_{50}$ values of test chemicals may need to differ by a considerable amount for chemicals to be classified as non-toxic. We found that $\mathrm{IC}_{50} \mathrm{ES}$ values of the in-house chemicals were close to their $\mathrm{ID}_{50}$ and $\mathrm{IC}_{50} 3 \mathrm{~T} 3$ values (Table 6). The ratios of $\mathrm{ID}_{50} / \mathrm{IC}_{50} \mathrm{ES}$ or $\mathrm{IC}_{50} 3 \mathrm{~T} 3 /$ $\mathrm{IC}_{50} \mathrm{ES}$ ranged from 0.5 to 2 in a majority of the in-house chemicals tested. Therefore, the in-house chemicals might be classified as weakly toxic rather non-toxic. When the data of the ECVAM validation test were analyzed, the values of the parameters were also close to one another.

\section{DISCUSSION}

We conducted cell-based developmental toxicity assays devised two decades apart and investigated their characteristics. The results indicated that both assays had high false positive rates. Chemicals tested included agrochemicals such as fungicides, insecticides, and herbicides; pharmaceuticals targeting the nervous, cardiovascular, and 
immune systems; and general chemical substances. In the MOT assay, there was little tendency that classification was related to chemical properties. The fact that a group of structurally and bioactively similar chemicals were classified as positive or negative almost at random might also suggest no particular relationship between chemical property and classification in vitro. The analysis of the EST assay results suggests that the basis for prediction may primarily be the inhibition of cell growth. Test chemicals including agrochemicals and pharmaceuticals are possibly physiologically active against cells, resulting in the inhibition of cell growth at higher concentrations. Therefore, all chemicals tested were classified as strongly or weakly embryotoxic. Concordance with in vivo developmental toxicity was not very different between the two assays despite the lapse of two decades between the introductions of these assays. This may suggest that little or no change has occurred in the fundamental predictivity of in vitro developmental toxicity assays while attempts have been made to incorporate contemporary findings in biology and to develop a more advanced in vitro assay. Many factors may contribute to the lack of substantial improvement in predictive accuracy. We believe the following are worth emphasizing.

Basically, an in vitro test is expected to capitalize on the specific bioactivities of chemicals underlying the assay principle. Generally, an in vitro assay principle is assumed to be the real mechanisms of developmental toxicity in animals. In the MOT and EST assays, however, not only developmentally toxic chemicals but also many non-toxic chemicals were classified as positive in vitro even though the assays were based on different principles, namely the inhibition of cell attachment (the MOT assay principle) and the suppression of heart beat development (or perhaps cell growth inhibition; the EST assay principle). This may show that the cells used in MOT and EST assays respond to many chemical signals. It is possible, therefore, that the assays detect non-specific signals regardless of whether they cause developmental toxicity in animals. Alternatively, the assay principles of MOT and EST may not be the real mechanisms of developmental toxicity in animals. The bioactivity-based assay principles guiding the in vitro assays might not be the same as those guiding the in vivo assay. Thus, the bioactivities assayed in vitro may be irrelevant to developmental toxicity in vivo. As a result, many developmental toxicants as well as non-toxic chemicals might be classified as positive because of the non-specificity or irrelevance of the MOT and EST assay principles, leading to inaccurate prediction with a high false positive rate.

In addition, the selection of reference chemicals as developmental toxicants may be another important issue affecting the inaccuracy of prediction and false positives. The principles of MOT and EST assays probably apply to

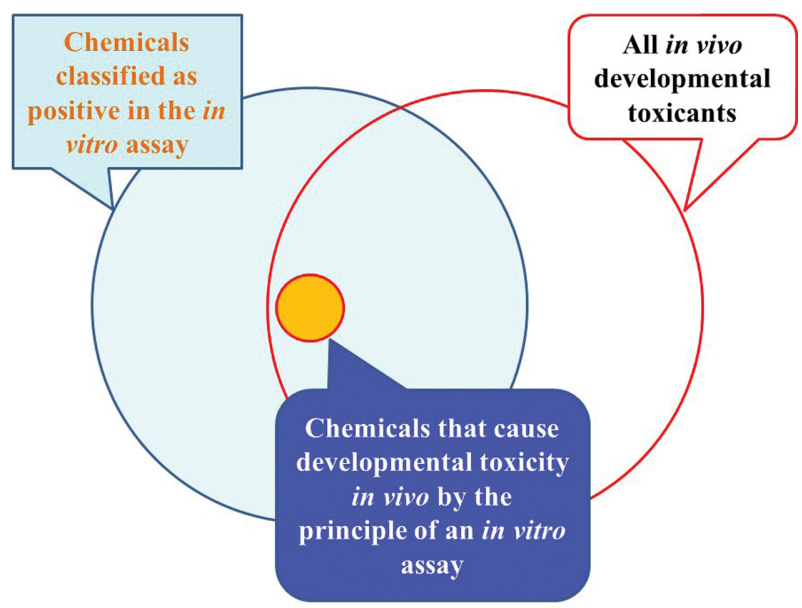

Fig. 2. A conceptual representation explaining the presence of false positives in an in vitro assay. The circle outlined in red shows the entire collection of chemicals that cause developmental toxicity in vivo caused by any mechanism. The orange circle represents only those chemicals that cause developmental toxicity in vivo by the principal mechanisms in the mechanism-based in vitro assays; these represent a small part of the whole. The light blue circle represents chemicals classified as positive in the in vitro assay. A considerable number of chemicals cause developmental toxicity by mechanisms other than the principal mechanisms (overlap of the circle outlined in red and the light blue circle, exclusive of the orange circle). In a strict sense, these are incorrectly detected as positive. Nevertheless, such in vitro assays may have been evaluated as good models (single tests) for detecting many developmentally toxic chemicals, possibly leading to the high false positive rates of in vitro assays.

only a very small number of pathogenetic mechanisms of developmental toxicity (Fig. 2) even when the assay principle is based on real mechanisms of developmental toxicity in animals. We pursued, however, to detect all developmental toxicants with the MOT or EST assay. We evaluated the performance of the MOT and EST assays with a variety of chemicals which induce developmental toxicity by different pathogenetic mechanisms. In vivo developmental toxicants regardless of pathogenetic mechanisms were used as positive reference chemicals. Only the chemicals that cause developmental toxicity by inhibiting cellcell attachment should be detected in the MOT assay. Only chemicals that cause developmental toxicity by inhibiting heart beat development should be detected in the EST assay. From this perspective, a considerable number of chemicals that cause developmental toxicity by mechanisms other than these assay principles (intersection of the circle outlined in red and the light blue circle, exclusive of the orange circle in Fig. 2) were, in a strict sense, incorrectly characterized as positive. These chemicals should have been used as negative reference substances, not positives, and classified as negative in the assays even though 
they are developmentally toxic by other mechanisms.

Not a few in vitro developmental toxicity assays may have been impacted by similar issues. It is likely that false positives are intrinsic to in vitro assays as long as we attempt to detect all developmentally toxic chemicals using a single in vitro assay whose principle is based on a limited number of pathogenetic mechanisms. Nevertheless, the in vitro assays, MOT and EST, might be regarded as suitable methods for detecting many developmentally toxic chemicals in a single test. Such assays may have been proposed for in vitro testing and adopted even though their detection of in vivo developmental toxicity might not be genuine. A key approach to address these issues can be to develop in vitro assays whose principles are based on well-elucidated, and not on assumed pathogenetic mechanisms of developmental toxicity. Assays should be validated with chemicals that have clear mechanisms of developmental toxicity. Chemicals causing developmental toxicity in animals through the pathogenetic mechanisms that are the basis of the assay principles should be referred to as positive. Unfortunately, few pathogenetic mechanisms of developmental toxicity have been elucidated. The elucidation of these mechanisms is a necessary fundamental study towards establishing a truly reliable in vitro assay.

The concordance rates for the MOT and EST assays were at the $60 \%$ level. In dichotomizing test agents into positive and negative, the base rate of concordance (in the case of classification completely by chance) is $50 \%$, not $0 \%$, because a random answer to a binary-choice (yes or no) question is coincidentally correct $50 \%$ of the time. A test with concordance rate of $60-70 \%$ or perhaps $80 \%$ may not have special significance as a screen for candidate chemicals, and for ranking agents for follow-on in vivo test since the test results may be just coincidence. Other endpoints or parameters such as physicochemical characteristics, physiological activity, and bioavailability may serve as useful data for prioritizing and reducing the number of substances to be tested.

Whether a high false positive rate in an in vitro assay is an advantage or disadvantage depends largely on what the in vitro assay is used for. Unfortunately, both in vitro assays, MOT and EST, were considered not to be generally applicable to screening for the developmental toxicity of our candidate chemicals that are still in early-stage development. Recent adoption of alternative experimental animal tests has mandated further development of in vitro methods for safety evaluation. New technologies such as omics technology and newly available materials including human cells and tissues are expected to facilitate development of more effective and appropriate in vitro human safety assessment methods. However, at this time, when chemicals in the market including pharmaceuticals, cosmetics, biocides, and pesticides are tested using in vitro developmental toxicity tests, especially with human cells or tissues, positive results should be scrutinized and carefully interpreted. In addition, scrutinization and interpretation should be carried out taking into account all available clinical and non-clinical data regarding the developmental toxicity of the chemicals and possible high false positive rates of the in vitro assays. We should avoid unnecessary termination of pregnancy in expectant women who fear possible chemical exposure.

\section{ACKNOWLEDGMENTS}

The authors would like to thank Dr. Kunifumi Inawaka and the staff of Sumitomo's Developmental and Reproductive Biology Team for their excellent assistance.

\section{CONFLICT OF INTEREST}

The authors have no conflicts of interest to declare.

The views expressed in this article are those of the authors and do not necessarily reflect the views or policies of Sumitomo Chemical Co. Ltd.

Received March 4, 2019; Revised April 8, 2019; Accepted April 25, 2019

\section{REFERENCES}

1. Kimmel, G.L., Smith, K., Kochhar, D.M. and Pratt, R.M. (1982) Proceedings of the consensus workshop on in vitro teratogenesis testing. Teratog. Carcinog. Mutagen., 2, i-v.

2. Fantel, A.G. (1982) Culture of whole rodent embryos in teratogen screening. Teratog. Carcinog. Mutagen., 2, 231242.

3. Jelinek, R. (1982) Use of chick embryo in screening for embryotoxicity. Teratog. Carcinog. Mutagen., 2, 255-261.

4. Johnson, E.M., Gorman, R.M., Gabel, B.E.G. and George, M.E. (1982) The hydra aftenuata system for detection of teratogenic hazards. Teratog. Carcinog. Mutagen., 2, 263276.

5. Best, J.B. and Morita, M. (1982) Planarians as a model system for in vitro teratogenesis studies. Teratog. Carcinog. Mutagen., 2, 277-291.

6. Schuler, R.L., Hardin, B.D. and Nierneier, R.W. (1982) Drosophila as a tool for the rapid assessment of chemicals for teratogenicity. Teratog. Carcinog. Mutagen., 2, 293-301.

7. Keller, S.J. and Smith, M.K. (1982) Animal virus screens for potential teratogens. I. Poxvirus morphogenesis. Teratog. Carcinog. Mutagen., 2, 361-374.

8. Kochhar, D.M. (1982) Embryonic limb bud organ culture in assessment of teratogenicity of environmental agents. Teratog. Carcinog. Mutagen., 2, 303-312.

9. Pratt, R.M., Grove, R.I. and Willis, W.D. (1982) Prescreening for environmental teratogens using cultured mesenchymal cells from the humanembryonic palate. Teratog. Carcinog. Mutagen., 2, 313-318. 
10. Greenberg, J.H. (1982) Detection of teratogens by differentiating embryonic neural crest cells in culture: Evaluation as a screening system. Teratog. Carcinog. Mutagen., 2, 319-323.

11. Braun, A.G., Nichinson, B.B. and Horowicz, P.B. (1982). Inhibition of tumor cell attachment to concanavalin Acoated surface as an assay for teratogenic agents: approaches to validation. Teratog. Carcinog. Mutagen., 2, 343-354.

12. Wilson, J.G. (1978) Review of in vitro systems with potential for use in teratogenicity screening. J. Environ. Pathol. Toxicol., 2, 149-167.

13. Braun, A.G., Emerson, D.J. and Nichinson, B.B. (1979) Teratogenic drugs inhibit tumour cell attachment to lectincoated surfaces. Nature, 282, 507-509.

14. Braun, A.G., Buckner, C.A., Emerson, D.J. and Nichinson, B.B. (1982). Quantitative correspondence between the in vivo and in vitro activity of teratogenic agents. Proc. Natl. Acad. Sci. U.S.A., 79, 2056-2060.

15. Spielmann, H., Seiler, A., Bremer, S., Hareng, L., Hartung, T., Ahr, H., Faustman, E., Haas, U., Moffat, G.J., Nau, H., Vanparys, P., Piersma, A., Sintes, J.R. and Stuart, J. (2006) The practical application of three validated in vitro embryotoxicity tests. Altern. Lab. Anim., 34, 527-538.

16. Chapin, R., Augustine-Rauch, K., Beyer, B., Daston, G., Finnell, R., Flynn, T., Hunter, S., Mirkes, P., O'Shea, K.S., Piersma, A., Sandler, D., Vanparys, P. and Van Maele-Fabry,
G. (2008) State of the art in developmental toxicity screening methods and a way forward: A meeting report addressing embryonic stem cells, whole embryo culture, and zebrafish. Birth Defects Res. B Dev. Reprod. Toxicol., 83, 446-456.

17. Hong, E.-J. and Jeung, E.-B. (2013) Assessment of developmental toxicants using human embryonic stem cells. Toxicol. Res., 29, 221-227.

18. Scholz, G., Genschow, E., Pohl, I., Bremer, S., Paparella, M., Raabe, H., Southee, J. and Spielmann, H. (1999) Prevalidation of the embryonic stem cell test (EST) - a new in vitro embryotoxicity test. Toxicol. In Vitro, 13, 675-681.

19. Braun, A.G. and Dailey, J.P. (1981) Thalidomide metabolite inhibits tumor cell attachment to concanavalin A coated surfaces. Biochem. Biophys. Res. Commun., 98, 1029-1034.

20. Genschow, E., Spielmann, H., Scholz, G., Pohl, I., Seiler, A., Clemann, N., Bremer, S. and Becker, K. (2004) Validation of the embryonic stem cell test in the international ECVAM validation study on three in vitro embryotoxicity tests. Altern. Lab. Anim., 32, 209-244.

21. Paquette, J.A., Kumpf, S.W., Streck, R.D., Thomson, J.J., Chapin, R.E. and Stedman, D.B. (2008) Assessment of the embryonic stem cell test and application and use in the pharmaceutical industry. Birth Defects Res. B Dev. Reprod. Toxicol., 83, 104-111. 